\title{
Determining the factors that influence the occurrence of Bare-faced Curassows (Crax fasciolata) in Humid Chaco, northern Argentina
}

\author{
Sofía Zalazar ${ }^{1}$, Alejandro L. Benitez ${ }^{2}$ and Adrián S. Di Giacomo ${ }^{1}$ \\ ${ }^{1}$ Centro de Ecología Aplicada del Litoral (CECOAL-CONICET), Ruta 5, km 2.5, (3400) Corrientes, Argentina, ${ }^{2}$ The Conservation \\ Land Trust Argentina, Scalabrini Ortiz 3355, 4!J, (1425) Buenos Aires, Argentina
}

ABSTRACT. Identifying factors that determine the spatial distribution of threatened species is key to ensuring their conservation. The
Bare-faced Curassow (Crax fasciolata) is a globally threatened bird that is categorized as Vulnerable, and its populations are declining
in the gallery forests of the Humid Chaco. To evaluate the effect of human activities and environmental characteristics on the occupancy
of Bare-faced Curassows, we sampled 48 sites along two rivers in northern Argentina. Bare-faced Curassows were recorded in $46 \%$ of
the sites visited. The anthropic activities were identified as hunting pressure, selective logging of timber, and livestock production.
Hunting and logging were positively associated with each other, and in turn, negatively related to village distance. We evaluated 17
occupancy models using six predictive variables. Occupancy by the Bare-faced Curassow was positively influenced by the distance to
the nearest village and by forest cover. To a lesser extent, occupancy was also positively associated with an increase in availability of
trees with fleshy fruits and with river course length. Our results indicate that hunting pressure and selective logging are limited by the
cost of access from populated areas. Thus, distance to the villages was a good indicator of these human activities along the gallery
forests and could be used to determine the spatial distribution of the Bare-faced Curassow in its southern range. Our study highlights
the value of using presence/absence surveys and occupancy models for assessing threats of threatened and elusive species such as cracids.

\section{Identification des facteurs qui influent sur l'occurrence du Hocco à face nue (Crax fasciolata) dans le Chaco humide du nord de l'Argentine}

RÉSUMÉ. L'identification des facteurs qui influent le plus sur la répartition spatiale d'espèces menacées est fondamentale si l'on veut assurer leur conservation. Le Hocco à face nue (Crax fasciolata) est un oiseau menacé à l'échelle planétaire et classé comme « vulnérable "; ses populations sont en diminution dans les forêts-galeries du Chaco humide. Pour évaluer l'effet des activités humaines et des caractéristiques environnementales sur la présence des Hoccos à face nue, nous avons échantillonnés 48 sites le long de deux rivières dans le nord de l'Argentine. Des Hoccos à face nue ont été trouvés dans $46 \%$ des sites visités. Les activités d'origine anthropique qui ont été identifiées sont la pression de chasse, la coupe sélective de bois et l'élevage de bétail. La chasse et la coupe de bois étaient positivement associées l'une à l'autre, mais négativement liées à la distance d'un village. Nous avons évalué 17 modèles de présence au moyen de six variables explicatives. La présence du Hocco à face nue était positivement associée avec la distance au village le plus proche et le couvert forestier. Dans une plus faible mesure, la présence du hocco était aussi positivement associée avec une quantité supérieure d'arbres à fruits charnus et la longueur du cours d'eau. Nos résultats indiquent que la pression de chasse et la coupe sélective sont limitées par le coût d'accès à partir de régions populeuses. Ainsi, la distance des villages était un bon indicateur d'activités humaines le long des forêts-galeries et pourrait être utilisée pour déterminer la répartition spatiale du hocco dans le sud de son aire. Notre étude souligne la valeur de l'utilisation de relevés de présence/absence et de modèles de présence pour évaluer les menaces d'espèces menacées et discrètes comme les cracidés.

Key Words: conservation; Cracidae; gallery forests; human impact; hunting; logging

\section{INTRODUCTION}

Understanding the factors that determine the presence of threatened species contributes to effective conservation and management strategies (Caughley 1994, Guisan et al. 2013). Species distribution on a regional scale is related mainly to climatic and biogeographic environmental factors (Rahbek and Graves 2001, Willis and Whittaker 2002, Pearson and Dawson 2003), and at a local scale, with other factors such as habitat availability (Fahrig 2001), presence of specific resources (Guisan and Thuiller 2005), and interaction with other species (Wisz et al. 2013). However, the current distribution of many threatened species is also limited by threats associated with human activities such as hunting pressure (Benitez-Lopez et al. 2017), and habitat loss and fragmentation (Thornton et al. 2012).

The family Cracidae includes chachalacas, guans, and curassows, which are large birds $(>1 \mathrm{~kg})$ that inhabit Neotropical forests (del Hoyo 1994). It is one of the most threatened bird families in the world, with $50 \%$ of species in some category of extinction risk (Birdlife International 2017). The main threats to cracids are hunting pressure and habitat loss (Cancino and Brooks 2006). As large frugivores, cracids play a key role in the functioning of 
Table 1. Description of ecological and human variables, their predicted influence on occupancy $(\Psi)$, on detection probability (p), and a priori hypothesis $(\beta 1)$ for modeling the occupancy of Bare-faced Curassow of the Humid Chaco, northern Argentina. The variables with an asterisk were not included in the occupancy models.

\begin{tabular}{|c|c|c|c|c|}
\hline Variables & Code & Description & Predicted effect & A priori hypothesis \\
\hline Distance village & Dist & $\begin{array}{l}\text { Linear distance from the center of the } \\
\text { sites to the nearest village }(\mathrm{km})\end{array}$ & Positive $(\Psi)$ & $\begin{array}{l}\beta_{1}<0 \text {, occupancy increases as the distance to the } \\
\text { village increases }\end{array}$ \\
\hline Forest cover & $\mathrm{Cov}$ & Percentage of forest cover in each site $(\%)$ & Positive ( $\Psi$ ) & $\begin{array}{l}\beta_{1}>0 \text {, occupancy increases as the forest cover } \\
\text { increases }\end{array}$ \\
\hline Cattle & Cattle & $\begin{array}{l}\text { Number of trails and trace of cattle } \\
\text { (count) }\end{array}$ & Negative ( $\Psi)$ & $\begin{array}{l}\beta_{1}>0 \text {, occupancy decreases as the trace of cattle } \\
\text { increases }\end{array}$ \\
\hline River length & River & Length of river within each site $(\mathrm{km})$ & Positive $(\Psi)$ & $\begin{array}{l}\beta_{1}<0 \text {, occupancy increases as the length of river } \\
\text { increases }\end{array}$ \\
\hline Fruit trees & Fruit & $\begin{array}{l}\text { Number of fruit trees available as food } \\
\text { resource (count) }\end{array}$ & Positive $(\Psi)$ & $\begin{array}{l}\beta_{1}<0 \text {, occupancy increases as the food resource } \\
\text { increases }\end{array}$ \\
\hline Logging* & $\log$ & $\begin{array}{l}\text { Presence of remains of trees felled and } \\
\text { discarded wood }\end{array}$ & Negative ( $\Psi)$ & $\beta_{1}>0$, occupancy is less where there is logging \\
\hline Hunting* & Hunt & $\begin{array}{l}\text { Presence of hunters, shots, and traces of } \\
\text { recent hunting activity }\end{array}$ & 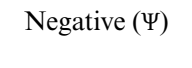 & $\beta_{1}>0$, occupancy is less where there is hunting \\
\hline Observers & Obs & $\begin{array}{l}\text { Number of observers at each visited } \\
\text { (count) }\end{array}$ & Positive (p) & $\begin{array}{l}\beta_{1}<0 \text {, detection increases as the number of } \\
\text { observers increases }\end{array}$ \\
\hline
\end{tabular}

forests, so their local extinction could generate changes in the abundance of plants (Muñoz and Kattan 2007, Bueno et al. 2013, Galetti et al. 2013, 2016).

The Bare-faced Curassow (Crax fasciolata) inhabits humid semideciduous and gallery forests of Brazil, Bolivia, Paraguay, and Argentina (del Hoyo and Motis 2004). Despite its wide distribution, little is known about its ecology (Cancino and Brooks 2006). Bare-faced Curassows have recently been categorized as globally Vulnerable (Birdlife International 2017) based on a recent model of deforestation in Amazonia that reevaluated Amazonian birds (Bird et al. 2011, Tracewski et al. 2016). In Argentina, Bare-faced Curassow populations have disappeared from most of their historical range, and the species is currently restricted to the gallery forests in the northeastern provinces of Formosa and Chaco (White 2001, Chebez et al. 2008, MAyDS and AA 2017).

Occupancy modeling is a powerful tool used to make inferences about the spatial distribution and habitat use of rare or elusive species with behaviors that hinder their detection, as is the case of Bare-faced Curassows (Mackenzie et al. 2006, O'Connell and Bailey 2011). These models incorporate the probability of detection and simultaneously estimate occupancy and detection probabilities of a species on a site through repetitive sampling performed over a short period of time (Mackenzie and Royle 2005, Mackenzie et al. 2006). In this way, imperfect detection is taken into account and "false absences" are eliminated, thus avoiding biased estimations (Mackenzie et al. 2002).

The goal of our work was to use occupancy models to study the environmental and human factors that determine the current distribution of Bare-faced Curassow populations in northern Argentina. We hypothesized that logging, hunting pressure, and presence of livestock would all have a strong negative influence on the Bare-faced Curassow's distribution, while village distance, forest cover, availability of fleshy fruit trees, and length of river would have a positive effect (Table 1). Logging would have a negative influence because it produces changes in the forest structure, generates forest gaps, and increases accessibility to the gallery forest by hunters, livestock, and agriculture. Hunting pressure would also have a negative effect because removing individuals of a long-lived species with a low reproductive rate, as is the case of the Bare-faced Curassow, would have a greater impact on the population's recruitment. Livestock presence in the forest would change the forest's structure and affect the species richness, which would negatively influence the Bare-faced Curassow's presence. These human activities would decrease with village distance; therefore, the distance to the village would have a positive effect on the distribution of this species. Forest cover, availability of fleshy fruit trees, and presence of watercourses would be important ecological characteristics for the Bare-faced Curassow presence.

\section{METHODS}

\section{Study area}

Humid Chaco is one of the subregions of the Gran Chaco ecoregion of South America. It is composed of lowland savanna with an extensive matrix of pastures and wetlands, where patches of different types of forests are dispersed (Guinzburg and Adámoli 2005). The climate is subtropical, with an average annual temperature of $22^{\circ} \mathrm{C}$ and average annual precipitation of 1300 $\mathrm{mm}$ (Placci and Holz 2004). Rainfall is seasonal, with a winter minimum (monthly average of $50 \mathrm{~mm}$ ) and a summer maximum (monthly average of $150 \mathrm{~mm}$ ) but with a tendency toward a double peak at the end of spring $(200 \mathrm{~mm})$ and a greater one at the beginning of autumn (220 mm) (Guinzburg and Adámoli 2005).

Gallery forests occur along rivers that cross the Humid Chaco savanna. Although these forests never exceed $1000 \mathrm{~m}$ in width, they are the second most biodiverse habitat in Argentina (Brown et al. 2006). In spite of their high conservation value, the percentage of gallery forests protected is low $(<1 \%)$ (Ginzburg and Adámoli 2005). The structure of these forests is stratified; they have a canopy at $15 \mathrm{~m}$ with emergent trees that can be up to $25 \mathrm{~m}$ tall (Placci 1995). The understory is open at low altitudes 
Fig. 1. Location of the study areas along the gallery forests of the Monte Lindo and Pilagá Rivers in the Humid Chaco, northern Argentina. Gray hexagons represent the 48 sites surveyed.

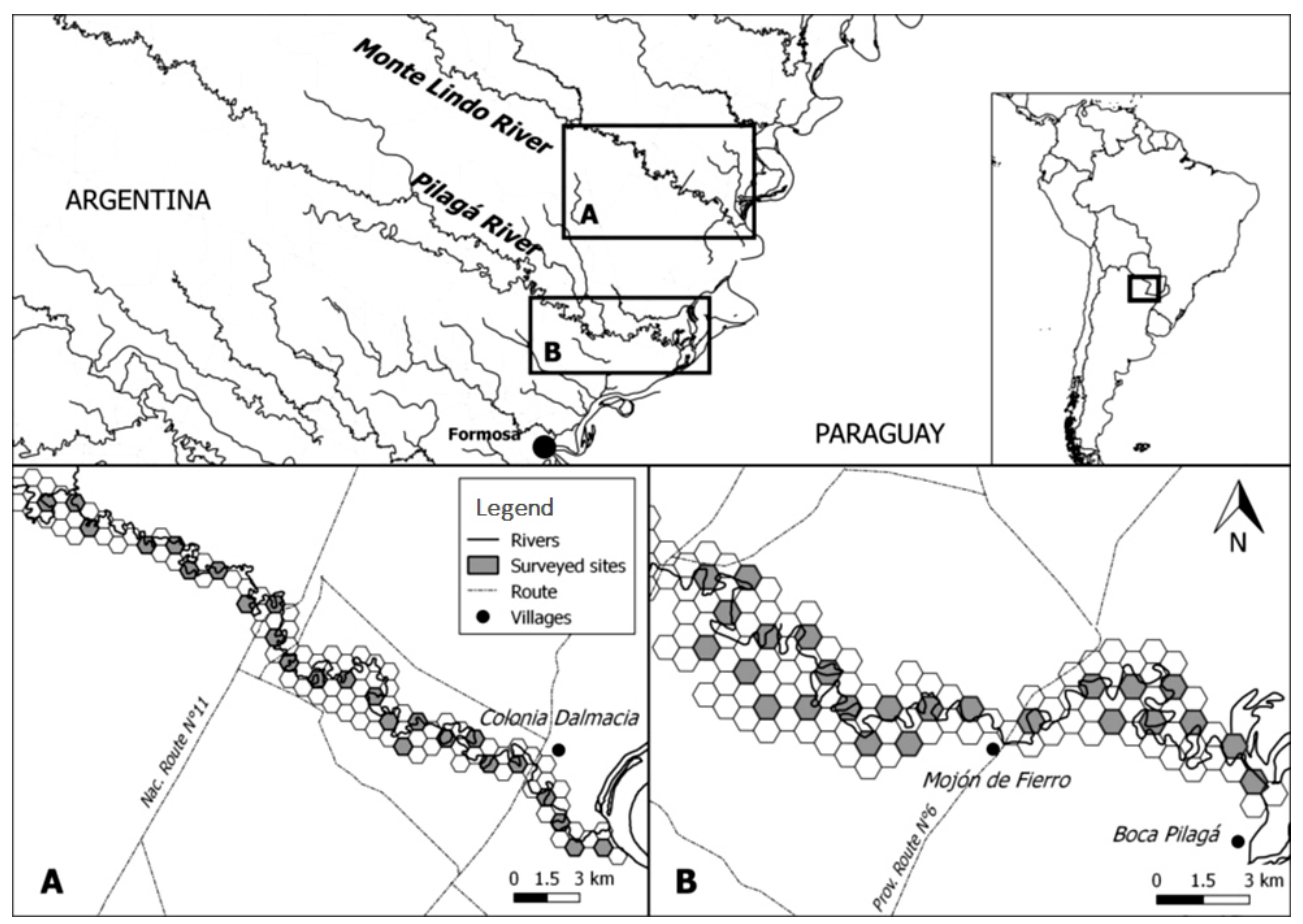

but is denser at intermediate altitudes, and the soil is shady, covered with scattered shrubs and bromeliads (Placci and Holz 2004). The lowest elevational sector of these forests is subject to an average of 108 days of flooding per year (Placci and Holz 2004).

We carried out our study in the gallery forests of the Monte Lindo and Pilagá Rivers, in the eastern area of the province of Formosa, where the main Bare-faced Curassow populations of Argentina are currently located (Fig. 1). There are two small-populated areas: Colonia Dalmacia on the Monte Lindo River, which has 200 human inhabitants, and Mojón de Fierroon on the Pilagá River, which has 3000 inhabitants. The primary anthropic activity in the study area is livestock production, although local people perform other activities such as timber extraction, fishing, and hunting.

\section{Sampling sites}

To select the sites in our study area, we generated a grid of hexagonal cells over a satellite image of the gallery forests of both rivers, covering a total area of $120 \mathrm{~km}^{2}$. From the grid, we randomly selected 50 hexagons (Fig. 1). We defined the area of each site as a hexagon of 50 ha, which is considered to be the size of the core territory of Crax (ranges from 20 to 200 ha) (Bertsch and Barreto 2008a, de Coster 2011) and takes into account the constraints of the linear layout and small size of gallery forests in the study area.

\section{Data collection}

We carried out fieldwork from June to August 2016. At each site, we conducted transect surveys that were designed a priori according to the disposition of the rivers and the forests in each site, and which were parallel and perpendicular to the rivers and had a length of between 2 and $4 \mathrm{~km}$. We designed transects as straight lines, but when there was water inside the forest or the understory was dense, we walked where we could, always keeping the original direction. We surveyed each site three times between 0700 and 1800 hours. Due to logistics, accessibility, safety, and time constraints, some sites were visited by one observer and others by two. Both observers had previous experience in monitoring and investigation of this species. We conducted the surveys of each site either on the same day or on consecutive days in order to ensure that occupancy status of the sites did not change during the study period. In order to ensure the assumption of survey independence, we separated surveys by a minimum of one hour, as recommended by Mackenzie et al. (2004). To avoid a possible "time of day" effect, we ensured that all sites were sampled during the same times of the day.

During each survey, we recorded the presence/absence of Barefaced Curassows. Presence was defined either through direct observation or "alarm" vocalizations. In each site, we recorded eight variables related to habitat and anthropogenic activities that could affect the probability of occupancy (Table 1). We selected these variables because we expected a higher probability of occupancy in sites where logging, hunting, and livestock activities were absent, and where village distance, availability of trees with fleshy fruit, forest cover, and length of the river were greater (Wallace et al. 2001, Muñoz et al. 2007, Denis et al. 2016).

Within each site, we recorded the human activities as discrete variables. Evidence of hunting presence included encounters with hunters, shots heard, and traces of recent hunting activity (evidence of campfires, cartridges, and hunted animals remains). 
Evidence of logging activity included remains of trees cut down by chainsaws and discarded wood. Thus, we transformed logging and hunting activities into dichotomous variables (presence/ absence). We considered cattle raising to be present when cattle or their traces (as feces, observation, and tracks) were encountered along the transects. Also, we counted individuals of five species of trees whose fleshy fruit was previously identified as diet items of Bare-faced Curassows: Chrysophyllum gonocarpum, Plinia cauliflora, Ficus luschnathiana, Myrcianthes pungens, and Syagrus romanzoffiana (Zalazar, unpublished data). We determined the distance to the nearest village, forest cover percentage, and river course length within each site using ArcGIS software (version 10.3 ESRI, Redlands, California, USA). We also included the observer effect as a detection covariate (Mackenzie et al. 2004). We standardized discrete variables by the length of each transect surveyed, and then all variables were z-transformed, such that the mean was equal to zero.

\section{Data analysis}

To assess the effect of variables on the occupancy probability of Bare-faced Curassows $(\Psi)$, we constructed single-season occupancy models that were developed by MacKenzie et al. (2006). This approach has four assumptions: (1) the occupancy status of the sites does not change during the study period (the sites are "closed"); (2) the probability of occupancy is the same in all sites, or the differences in the probability of occupancy are modeled using variables; (3) the probability of detection of the species is the same in all sites or is a function of the site variables; and (4) detection of the species and detection history are independent between sites (MacKenzie et al. 2006).

We built a detection history with three surveys for each site. In the case in which one of the three surveys in a site could not be conducted, that survey was considered to be "missing" (Mackenzie et al. 2006). To avoid multicollinearity of anthropogenic variables, we evaluated the relationship between hunting and logging presence using Pearson's Chi-square test, and we modeled their relationship with village distance using generalized linear models with a binomial distribution (McCullagh 1984). We employed a stepwise regression (Crawley 2007), and carried out all analyses using $\mathrm{R}$ software (version 3.4.4, R Core Team 2018).

We generated all potential models using "unmarked" package in R (Fiske and Chandler 2011). First, we evaluated the simplest model in which we assumed that the probability of occupancy and detection were constant. We then incorporated predictor variables related to occupancy and detection with a logit link function. We limited the number of parameters according to the number of detections in the data set (Mackenzie et al. 2006), so we evaluated models with up to five parameters, including the intercept and the probability of detection.

To identify the best models, we used the Akaike information criteria (AIC) corrected for small samples (Akaike 1973, Burnham and Anderson 2002). Models with $\triangle \mathrm{AICc}<2$ were considered to be the most parsimonious models. We evaluated overdispersion by means of the bootstrap goodness-of-fit test ( $n$ $=1000$, bootstrap samples) (Mackenzie and Bailey 2004). We generated an average model and evaluated the relative importance of each covariate and the magnitude of the effect of each one on the occupation probability by calculating the $95 \%$ confidence intervals of the $\beta$ coefficients, using the fitting function "model. avg" of the "MuMIn" package (Burnham and Anderson 2002). When the confidence interval did not include zero, we considered the effect of the covariate to significant (Manly et al. 2002).

From the construction of the average model, we estimated the probability of conditional occupation for each site sampled $\left(\Psi_{i}^{\wedge}\right)$, and then we calculated the average conditional occupation probability $(\Psi)$ for the entire study area (with a $95 \%$ confidence interval).

\section{RESULTS}

We visited 48 sites, and in each survey, we walked an average of $2.36 \pm 0.75 \mathrm{SE} \mathrm{km}$. We conducted a total of 134 surveys, with a total of $315 \mathrm{~km}$ walked. Bare-faced Curassows were detected at 22 sites, three in the Pilagá River area and 19 in the Monte Lindo River area $\left(\Psi_{\text {naive }}=0.47\right)$. We observed 89 individuals on 35 occasions. We identified 49 males and 26 females. The number of individuals in each detection varied between 1 and 6 , with an average of $2.5 \pm 1.5 \mathrm{SE}$. Fifty percent of the records occurred at a distance of less than $50 \mathrm{~m}$ from the river course, $29 \%$ between 51 and $100 \mathrm{~m}$, and the rest greater than $100 \mathrm{~m}$.

Logging and hunting pressure were significantly associated with each other $\left(\chi^{2}=6.5, \mathrm{df}=1, P<0.05\right)$. Logging showed a significant negative relation to village distance $\left(\beta=-0.35 \pm 0.12, \chi^{2}=\right.$ 6.08e-05, df $=1, P<0.05$ ) (Fig. 2a), while hunting pressure was negatively related to village distance $\left(\beta=-0.021 \pm 0.01, \chi^{2}=0.05\right.$, df $=1, P<0.05$ ) (Fig. 2b). Hence, we decided to incorporate only village distance as a covariate in the occupancy model.

Fig. 2. Presence of wood extraction (A) and hunting (B) in the sites surveyed in relation to village distance. The black line indicates the fitted relationship according to the generalized linear model.
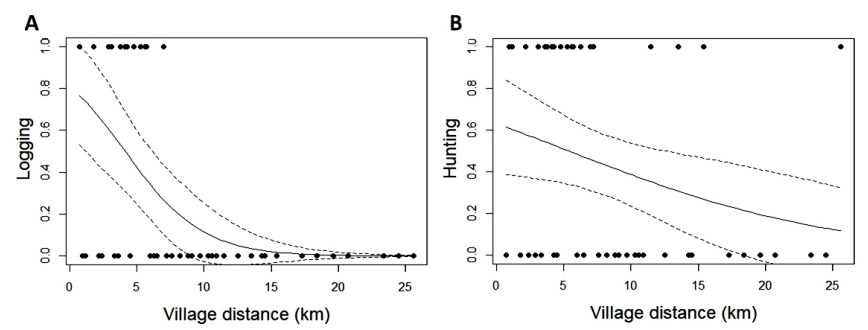

We built 17 models a priori using six variables. The three best models that explained Bare-faced Curassow occupancy included distance to the villages, forest cover, length of river course, and availability of fleshy fruit trees (Table 2). The top model, with lowest AICc and greatest Akaike weight (37\%), included distance to villages and forest cover. Livestock was not associated with any top-ranked model. Also, the probability of detection was not associated with any covariate and remained constant in all the sampling units $(p=0.46 \pm 0.08)$.

Occupancy increased as village distance, forest cover, river course length, and fleshy fruit tree availability increased (Fig. 3). Among these, village distance was the only variable with a strong effect on Bare-faced Curassow occupancy and had the greatest weight 
Table 2. Top occupancy models for Bare-faced Curassow of the Humid Chaco, northern Argentina. Information presented for each model: Quasi-Akaike's information criterion (AICc), change in AICc $(\triangle \mathrm{AICc})$, Akaike weights, number of parameters $(\mathrm{k})$, and deviance (-2log likelihood).

\begin{tabular}{|c|c|c|c|c|c|}
\hline Models & $\mathrm{AICc}$ & $\triangle \mathrm{AICc}$ & Weight & $\mathrm{k}$ & -2log likelihood \\
\hline$\Psi($ Distance + Cover $) \mathrm{p}()$. & 143.6 & 0 & 0.374 & 4 & -67.361 \\
\hline$\Psi($ Distance + River $) \mathrm{p}()$. & 144.4 & 0.81 & 0.25 & 4 & -67.764 \\
\hline$\Psi($ Distance + Fruit $)$ p(.) & 145.2 & 1.59 & 0.169 & 4 & -68.155 \\
\hline$\Psi($ Distance $) \mathrm{p}()$. & 146.4 & 2.77 & 0.094 & 3 & -69.934 \\
\hline$\Psi($ Distance + Cattle $) \mathrm{p}()$. & 148.0 & 4.37 & 0.042 & 4 & -69.545 \\
\hline$\Psi$ (Fruit + River) $\mathrm{p}()$. & 148.6 & 4.99 & 0.031 & 4 & -69.855 \\
\hline$\Psi($ Cover + River $)$ p(.) & 149.8 & 6.15 & 0.017 & 4 & -70.438 \\
\hline$\Psi($ Cover + Fruit) $p()$. & 151.4 & 7.80 & 0.008 & 4 & -71.259 \\
\hline$\Psi($ Fruit $) \mathrm{p}()$. & 152.4 & 8.76 & 0.005 & 3 & -72.931 \\
\hline$\Psi$ (River) $\mathrm{p}()$. & 152.7 & 9.06 & 0.004 & 3 & -73.079 \\
\hline$\Psi($ Fruit + Cattle) $p()$. & 153.4 & 9.80 & 0.003 & 4 & -72.261 \\
\hline$\Psi($ River + Cattle) $\mathrm{p}()$. & 154.3 & 10.65 & 0.002 & 4 & -72.686 \\
\hline$\Psi($ Cover $) \mathrm{p}()$. & 156.8 & 13.15 & 0.001 & 3 & -75.123 \\
\hline$\Psi(.) \mathrm{p}()$. & 157.6 & 13.98 & 0 & 2 & -76.675 \\
\hline$\Psi($ Cover + Cattle $) \mathrm{p}()$. & 158.1 & 14.50 & 0 & 4 & -74.61 \\
\hline$\Psi($ Cattle $) \mathrm{p}()$. & 158.8 & 15.17 & 0 & 3 & -75.556 \\
\hline$\Psi(.) \mathrm{p}($ Observers $)$ & 159.1 & 15.50 & 0 & 3 & -76.3 \\
\hline
\end{tabular}

Fig. 3. Modeled relationship between (A) village distance, (B) forest cover, $(C)$ fruit trees presence, (D) river length and the probability of site occupancy by Bared-face Curassow in the Humid Chaco, northern Argentina. Dotted lines indicate 95\% confidence intervals.
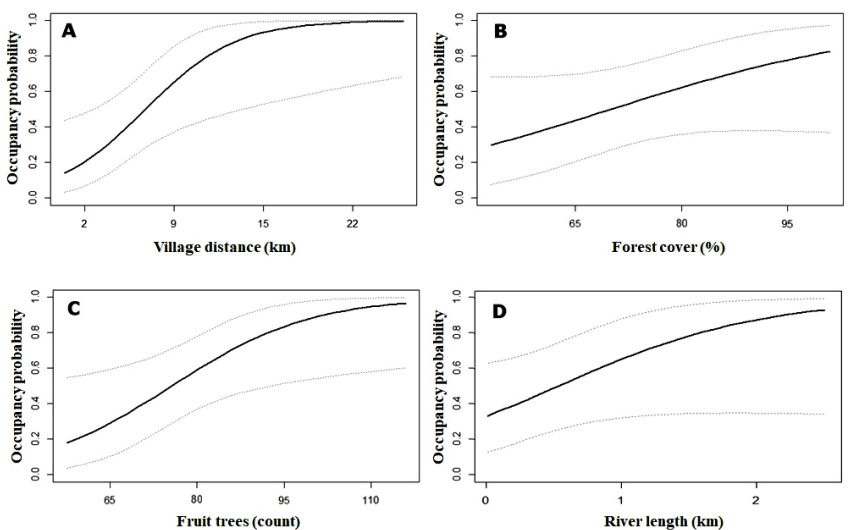

in the average model $(w=93 \%)$. This was followed by forest cover $(w=40 \%$ ) (Table 3 ). The probability of conditional occupancy $(\Psi)$ by the Bare-faced Curassow that was estimated for the study area was on average $0.55 \pm 0.16 \mathrm{SE}$ (Fig. 4). We found a greater occupancy of this species in the Monte Lindo River $(0.66 \pm 0.14$ $\mathrm{SE}$ ), where the human population is less and accessibility is more difficult compared with that of the Pilagá River $(0.43 \pm 0.18 \mathrm{SE})$. Also, distance from the villages to sites with the highest probability of occupation by the Bare-faced Curassow varied significantly between the rivers (Fig. 5).

\section{DISCUSSION}

Our results indicate that the hunting of wild animals and wood extraction in the gallery forest is facilitated by the proximity of
Fig. 4. Maps of conditional occupancy probability for Baredface Curassow in the Humid Chaco, northern Argentina. The conditional occupancy probability was estimated by the average model for this species.

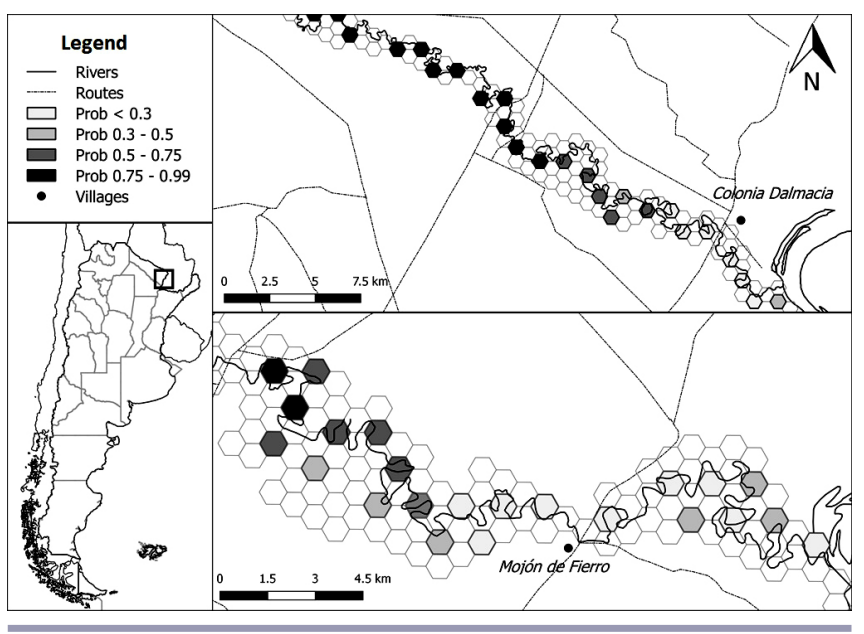

villages and accessibility to the rivers from the villages. These anthropic effects could limit the distribution of Bare-faced Curassows in gallery forests in northeastern Argentina. We also found that the decrease in forest cover negatively affected occupancy by Bare-faced Curassows along the rivers. Most species of cracids are threatened by human activities, including hunting (Barrio 2011, Kattan et al. 2015), as well as by forest loss and fragmentation (Melo-Vásquez et al. 2008, Thornton et al. 2012, Pardo et al. 2017). However, Kattan et al. (2015) suggest that hunting is the main threat to cracids. Moreover, several studies have reported that the Bare-faced Curassow is a species that is frequently hunted throughout its distribution (Townsend et al. 2002, Peres and Nascimento 2006, Cajaiba et al. 2015, de Paula et al. 2017). On the other hand, selective wood extraction 
Table 3. Parameter estimates $(\beta)$ with standard errors (SE), upper (UCI) and lower (LCI) $95 \%$ confidence intervals, and summary of Akaike weights of covariates for the average model of Barefaced Curassow of the Humid Chaco, northern Argentina.

\begin{tabular}{llllll}
\hline \hline Covariate & $\beta$ estimate & SE & UCI & LCI & Lwi \\
\hline psi (Intercept) & 0.5530818 & 0.6337193 & -0.6889852 & 1.7951487 & \\
p (Intercept) & -0.1170694 & 0.2762949 & -0.6585975 & 0.4244586 & 0.93 \\
psi (Distance) & 2.0099951 & 0.8447556 & 0.3543045 & 3.6656857 & 0.40 \\
psi (Cover) & 1.1246632 & 0.6544891 & -0.1581118 & 2.4074383 & 0.30 \\
psi (River) & 1.0004992 & 0.7824488 & -0.5330722 & 2.5340706 & 0.22 \\
psi (Fruit) & 1.2949133 & 0.7224673 & -0.1210965 & 2.7109232 & 0.05 \\
psi (Cattle) & -0.3859395 & 0.4501991 & -1.2683135 & 0.4964346 & $<0.01$ \\
p (Observers) & 0.4176482 & 0.4823110 & -0.5276640 & 1.3629603 & \\
\hline
\end{tabular}

Fig. 5. Modeled relationship between village distance and the probability of site occupancy by Bared-face Curassow. The dotted line indicates occupancy probabilities in both rivers, the black line in the Pilagá River, and the gray line in the Monte Lindo River.

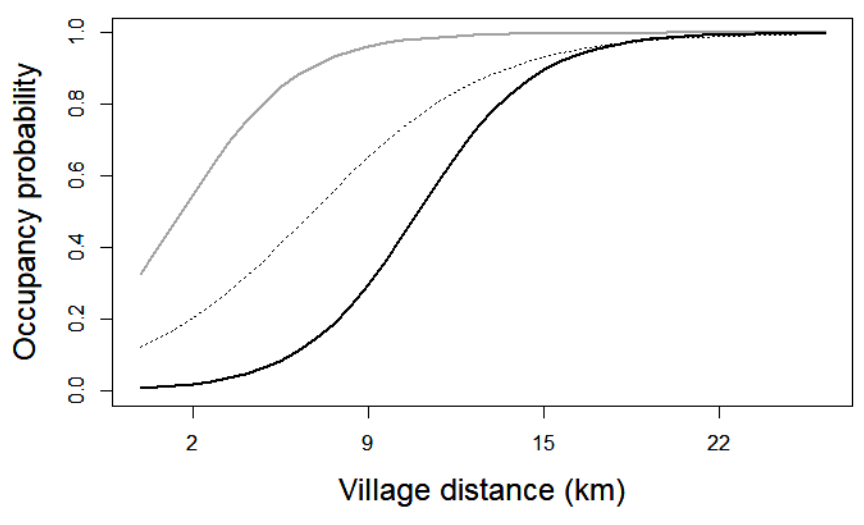

changes the structure of the Bare-faced Curassow's habitat by generating forest gaps, which are quickly covered by invasive shrubs. Furthermore, selective logging produces indirect disturbances because it increases accessibility to the gallery forest by hunters, livestock, and agriculture (Bennett and Robinson 2000, Putz et al. 2000).

Village distance explained much of the occupancy because it was a good proxy for the two main threats that the Bare-faced Curassow faces along the gallery forest of the rivers. In other studies, distance to populated areas has been used as a variable of occupancy, assuming that distance can be an indirect measure of anthropic effects on wild animal populations (ArroyoRodríguez et al. 2008, Marinho et al. 2018, Pardo et al. 2017). However, in our work, we were able to measure these effects and confirm the direct relationship between hunting and selective logging with village distance. Berkunsky et al. (2014) proposed that this variable can be used to predict the range of spatial distribution of parrot species that are affected by human presence in the savannah of Beni, Bolivia. Considering this, it could be used as a key tool to identify important areas for the conservation of persecuted species, such as cracids.
In our occupancy models, we also identified the availability of fleshy fruit trees and affinity to the watercourses as important ecological characteristics for Bare-faced Curassow presence. This is because cracids are mainly frugivorous, and their diet is based primarily on fruits such as drupes, berries, and arils (Muñoz and Kattan 2007, Bertsch and Barreto 2008b). Likewise, the presence of Crax fasciolata near watercourses has been documented (Wallace et al. 2001, Fernández-Duque et al. 2013), as has that of other species in the genus (Alarcón-Nieto and Palacios 2008, Hill et al. 2008). However, such variables had a lower weight than the threats of anthropic origin.

We did not find an effect of the presence of cattle on Bare-faced Curassow occupancy. Livestock presence in the forest produces a change in plant structure and affects plant species richness (Stern et al. 2002, Macchi and Grau 2012, Lucas et al. 2016). The lack of association between livestock and Bare-faced Curassow occupancy could be due to livestock being ubiquitous throughout the study area because livestock production is the main economic activity in the region.

Following the criterion of Pardo et al. (2017) in which a species ceases to be rare when occupation is greater than $50 \%$, the Barefaced Curassow ceases to be rare $(\Psi>0.50)$ only after $7 \mathrm{~km}$ from small villages. If we dissect our results according to rivers, occupation was greater than 0.50 at about $2.5 \mathrm{~km}$ from Colonia Dalmacia (100 inhabitants) and about $10 \mathrm{~km}$ from Mojón de Fierro (3000 inhabitants). This may be due to increased hunting pressure, selective logging, and other disturbances that affect availability of resources and structure of forests (Bennett and Robinson 2000, Putz et al. 2000, Azevedo-Ramos et al. 2006, Pardo et al. 2017). Our results agree with a recent review by Benitez-Lopez et al. (2017), who analyzed 176 studies conducted in the tropics and found that game bird populations are depleted, on average, within $7 \mathrm{~km}$ of populated areas. They also state that a higher density of inhabitants implies a greater exhaustion of game species, given that game and subsistence hunting intensified near large cities.

We also showed that there was a skew toward males in our sampling (approximately 2:1 male to female ratio), which could be due to detection bias since males vocalize more and have conspicuous plumage, unlike females, which vocalize less and have cryptic plumage (del Hoyo 1994). Given that Bare-faced Curassow are territorial, they are commonly observed alone or in pairs (Desbiez and Bernardo 2011), but in winter they 
congregate with neighboring families, which would explain the observations of groups of up to six individuals during our study. The sex ratio and the size of the groups detected were similar to that found by Fernández-Duque et al. (2013) in a study conducted with camera traps.

\section{Conservation implications}

The current state of the Bare-faced Curassow in Argentina is critical. Its populations have been extirpated from the provinces of Misiones and Corrientes (MAyDS and AA 2017), and currently, populations remain in some gallery forests along the rivers in the eastern provinces of Chaco and Formosa. Only two small populations are protected at Rio Pilcomayo National Park and Guaycolec Provincial Reserve, both in the province of Formosa (Di Giacomo 2005). This reserve constitutes a very small proportion $(<1 \%)$ of the Humid Chaco habitat (Ginzburg and Adámoli 2005, Di Giacomo 2005), despite the Bare-faced Curassow's critical status and the importance of gallery forests as biological corridors and sites of high biodiversity.

The Bare-faced Curassow has recently been declared a Provincial Natural Monument of the provinces of Formosa (law $\mathrm{N}^{\circ}$ $1582 / 12$ ). Under this law, the hunting of this species is prohibited and penalized. However, in practice, there are not sufficient control agents to enforce the law. Therefore, we consider that the most urgent measure is the generation of an effective monitoring program and the control of game hunting, especially in easily accessible zones. Nevertheless, other actions are needed to conserve this species. We consider the best strategy to be the joint promotion of (1) the creation of state and private protected areas where populations remain, (2) reintroduction programs, and (3) local ecotourism programs. Ecotourism as well as the creation and maintenance of protected areas could play a key role in socioeconomic development in the local communities, which would enable both species conservation and the generation of local culture for conservation. Cracid reintroductions have been used as a conservation tool for the restoration of threatened species, as was the case with Crax blumenbachii (São Bernardo 2012), Pipile albipennis (Angulo and Barrio 2004), and Aburria jacutinga (Oliveira et al. 2016). Reintroduction and ecotourism are being carried out effectively in some parts of the Argentinean Chaco, as happens in Iberá - Corrientes province (Caruso and Jiménez Pérez 2013, Di Blanco et al. 2015, Zamboni et al. 2017), where local hunters started working as provincial park rangers or local guides, which created a socioeconomic change in the region. Another example of the application of these strategies is the case of the Pantanal regions (Tortato et al. 2017) or the case of the Mocagua island in Colombia, where local inhabitants work as guides for tourists who travel specifically to observe and learn about the rare species Crax globulosa (Bennet 2003). All these actions should be accompanied by strong education programs, information campaigns, and community engagement activities, such as those made in the Central Amazon, Brazil, by Chaves et al. (2017).

Our results highlight the importance of using occupancy models to study patterns of spatial distribution of elusive and/or threatened species, since incorporating imperfect detection improves the estimation of occupation at a low cost (MacKenzie et al. 2002, Marinho et al. 2018). We were able to provide evidence of an effect of distance to nearest village and of the inhabitants numbers on the distribution of the Bare-faced Curassow, and this information can be used to prioritize efforts to mitigate hunting pressure through local community and authority engagement. Given that the distance to populated areas, human population densities, and forest cover can be obtained from satellite images and databases, the results of our occupancy models could also be used to improve estimations of the current area of occupancy by the Bare-faced Curassow and other cracid species that have similar behavior and experience similar threats.

Responses to this article can be read online at: http://www.ace-eco.org/issues/responses.php/1241

\section{Acknowledgments:}

We thank Dirección de Recursos Naturales y Gestión, Formosa province, for allowing us to conduct this project of the "Fondo Nacional para el Enriquecimiento y Conservación de Los Bosques Nativos, Ley $N^{\circ} 26.331 "$. Research funding was provided by Agencia Nacional de Promoción de la Ciencia y la Tecnología (PICT-2014-3397), Rufford Small Grants, Association of Field Ornithologists (Bergstrom Award), and Banco de Galicia (Fondo para la Conservación Ambiental). We thank the staff of the Estancia La Emilia, and the families Mencia, Acosta, and Barrios for their help during fieldwork. Also, we thank MSc Melanie Browne for correcting the English of the manuscript. SZ was supported by a CONICET Doctoral Scholarship, and ASDG is Research Fellow of the CONICET.

\section{LITERATURE CITED}

Akaike, H. 1973. Maximum likelihood identification of Gaussian autoregressive moving average models. Biometrika 60:255-265. http://dx.doi.org/10.1093/biomet/60.2.255

Alarcón-Nieto, G., and E. Palacios. 2008. Estado de la población del pavón moquirrojo (Crax globulosa) en el bajo río Caquetá, Amazonía colombiana. Ornitología Neotropical 19:371-376.

Angulo, F., and J. Barrios. 2004. Evaluation of a potential reintroduction site for the White-winged Guan Penelope albipennis (Aves, Cracidae) in northern Peru. Oryx 38:448-451. http://dx.doi.org/10.1017/S0030605304000833

Arroyo-Rodríguez, V., S. Mandujano, and J. Benítez-Malvido. 2008. Landscape attributes affecting patch occupancy by howler monkeys (Alouatta palliata mexicana) at Los Tuxtlas, Mexico. American Journal of Primatology 70:69-77. http://dx.doi. org/10.1002/ajp.20458

Azevedo-Ramos, C., O. de Carvalho, and B. D. do Amaral. 2006 Short-term effects of reduced-impact logging on eastern Amazon fauna. Forest Ecology and Management 232:26-35. http://dx.doi. org/10.1016/j.foreco.2006.05.025

Barrio, J. 2011. Presión de caza sobre crácidos (Cracidae: Aves) en concesiones forestales en Perú. Revista Peruana de Biología 18:225-230. http://dx.doi.org/10.15381/rpb.v18i2.234

Benítez-López, A., R. Alkemade, A. M. Schipper, D. J. Ingram, P. A. Verweij, J. A. J. Eikelboom, and M. A. J. Huijbregts. 2017. 
The impact of hunting on tropical mammal and bird populations. Science 356:180-183. http://dx.doi.org/10.1126/science.aaj1891

Bennett, E. L., and J. G. Robinson. 2000. Hunting of wildlife in tropical forests: implications for biodiversity and forest peoples. World Bank Biodiversity Series No. 76. World Bank, Washington, D.C., USA.

Bennett, S. E. 2003. Crax globulosa en la isla Mocagua, Amazonas, Colombia. Bulletin of the Cracid Specialist Group 16:7-15.

Berkunsky, I., R. E. Cepeda, C. Marinelli, M. V. Simoy, G. Daniele, F. P. Kacoliris, J. A. Díaz Luque, F. Gandoy, R. M. Aramburú, and J. D. Gilardi. 2014. Occupancy and abundance of large macaws in the Beni savannahs, Bolivia. Oryx 50:113-120. http://dx.doi.org/10.1017/S0030605314000258

Bertsch, C., and G. R. Barreto. 2008a. Abundancia y área de acción del paují de copete ( Crax daubentoni) en los llanos centrales de Venezuela. Ornitología Neotropical 19:287-293.

Bertsch, C., and G. R. Barreto. 2008b. Diet of the Yellow-knobbed Curassow in the Central Venezuelan Llanos. Wilson Journal of Ornithology 120:767-777. http://dx.doi.org/10.1676/07-172.1

Bird, J. P., J. M. Buchanan, A. C. Lees, R. P. Clay, P. F. Develey, I. Yépez, and S. H. M. Butchart. 2011. Integrating spatially explicit habitat projections into extinction risk assessments: a reassessment of Amazonian avifauna incorporating projected deforestation. Diversity and Distributions 18:273-281. http://dx. doi.org/10.1111/j.1472-4642.2011.00843.x

BirdLife International. 2017. Species factsheet: Crax fasciolata. [online] URL: http://datazone.birdlife.org/species/factsheet/ Bare-faced-Curassow

Brown, A., U. Martinez Ortiz, M. Acerbi, and J. F. Corcuera. 2006. La situación ambiental argentina 2005. Fundación Vida Silvestre Argentina, Buenos Aires, Argentina.

Bueno, R. S., R. Guevara, M. C. Ribeiro, L. Culot, F. S. Bufalo, and M. Galetti. 2013. Functional redundancy and complementarities of seed dispersal by the last neotropical megafrugivores. PloS One 8(2):e56252. http://dx.doi.org/10.1371/ journal.pone. 0056252

Burnham, K. P., and D. R. Anderson. 2002. Model selection and inference: a practical information-theoretic approach. Second edition. Springer-Verlag, New York, USA. http://dx.doi. org/10.1007/978-1-4757-2917-7

Cajaiba, R. L., W. B. da Silva, and P. R. R. Piovesan. 2015. Animais silvestres utilizados como recurso alimentar em assentamentos rurais no município de Uruará, Pará, Brasil. Desenvolvimento e Meio Ambiente 34:157-168. http://dx.doi. org/10.5380/dma.v34i0.38889

Cancino, L., and D. M. Brooks. 2006. Conservando crácidos: la familia de aves más amenazadas de las Américas. Miscellaneous Publications of the Houston Museum of Natural Science 6. Houston, Texas, USA.

Caruso, F., and I. Jiménez Pérez. 2013. Tourism, local pride, and attitudes towards the reintroduction of a large predator, the jaguar
Panthera onca in Corrientes, Argentina. Endangered Species Research 21:263-272. http://dx.doi.org/10.3354/esr00519

Caughley, G. 1994. Directions in conservation biology. Journal of Animal Ecology 63:215-244.

Chaves, W. A., D. R. Valle, M. C. Monroe, D. S. Wilkie, K. E. Sieving, and B. Sadowsky. 2017. Changing wild meat consumption: an experiment in the Central Amazon, Brazil. Conservation Letters 11:1-10.

Chebez, J. C., A. Chiappe, and G. Teo. 2008. Los que se van: fauna argentina amenazada. Editorial Albatros, Buenos Aires, Argentina.

Crawley, M. J. 2007. The R book. Wiley, West Sussex, UK. http:// dx.doi.org/10.1002/9780470515075

de Coster, F. 2011. Ecologie du Hocco alector (Crax alector) en Guyane française: approche de l'occupation de l'espace. Thesis. Universita di Corsica Pasquale Paoli, Corsica, France.

de Paula, M., V. Xerente, and J. Pezzuti. 2017. Hunting and monitoring: community-based research in Xerente Indigenous Land, Brazilian Cerrado. Human Ecology Review 23:23-44. http:// dx.doi.org/10.22459/HER.23.01.2017.02

del Hoyo, J. 1994. Cracidae (Chachalacas, Guans and Curassows). Pages 310-363 in J. del Hoyo, A. Elliott, and J. Sargatal, editors. Handbook of the birds of the world. Lynx Edicions, Barcelona, Spain.

del Hoyo, J., and A. Motis. 2004. Update chapter. Pages 322-476 in J. Delacour and D. Amadon, editors. Curassows and related birds. Second edition. Lynx Edicions and the National Museum of Natural History, Barcelona, Spain and New York, USA.

Denis, T., B. Hérault, G. Jaouen, O. Brunaux, S. Guitet, and C. Richard-Hansen. 2016. Black Curassow habitat relationships in terra firme forests of the Guiana Shield: a multiscale approach. Condor 118:253-273. http://dx.doi.org/10.1650/CONDOR-15-28.1

Desbiez, A. L. J., and C. S. Sao Bernardo. 2011. Density estimates of the Bare-faced Curassow (Crax fasciolata) in the Brazilian Pantanal. Revista Brasileira de Ornitologia 19:385-390.

Di Blanco, Y. E., I. Jiménez Pérez, and M. S. Di Bitetti. 2015. Habitat selection in reintroduced giant anteaters: the critical role of conservation areas. Journal of Mammalogy 96:1024-1035. http://dx.doi.org/10.1093/jmammal/gyv107

Di Giacomo, A. S., editor. 2005. Áreas importantes para la conservación de las aves en Argentina: sitios prioritarios para la conservación de la biodiversidad. Temas de Naturaleza y Conservación 5, Aves Argentinas/Asociación Ornitológica del Plata, Buenos Aires, Argentina.

Fahrig, L. 2001. How much habitat is enough? Biological Conservation 100:65-74. http://dx.doi.org/10.1016/S0006-3207 (00)00208-1

Fernández-Duque, F., M. Huck, V. Dávalos, and E. FernándezDuque. 2013. Estudio preliminar sobre la ecología, el comportamiento y la demografía del Muitú (Crax fasciolata) en la selva en galería del riacho Pilagá, Formosa, Argentina. El Hornero 28:65-74. 
Fiske, I., and R. Chandler. 2011. unmarked: an R package for fitting hierarchical models of wildlife occurrence and abundance. Journal of Statistical Software 43:1-23. http://dx.doi. org/10.18637/jss.v043.i10

Galetti, M., R. Guevara, M. C. Côrtes, R. Fadini, S. V. Matter, A. B. Leite, F. Labecca, T. Ribeiro, C. S. Carvalho, R. G. Collevatti, M. M. Pires, P. R. Guimarães, P. H. Brancalion, M. C. Ribeiro, and P. Jordano. 2013. Functional extinction of birds drives rapid evolutionary changes in seed size. Science 340:1086-1090. http://dx.doi.org/10.1126/science.1233774

Galetti, M., A. S. Pires, P. H. S. Brancalion, and F. A. S. Fernandez. 2016. Reversing defaunation by trophic rewilding in empty forests. Biotropica 49:5-8. http://dx.doi.org/10.1111/ btp. 12407

Ginzburg, R., and J. Adámoli. 2005. Ecorregión Chaco Húmedo: Situación ambiental en el Chaco Húmedo. Pages 103-129 in A. Brown, U. Martinez Ortiz, M. Acerbi, and J. Corcuera, editors. La Situación Ambiental Argentina 2005. Fundación Vida Silvestre Argentina, Buenos Aires, Argentina.

Guisan, A., and W. Thuiller. 2005. Predicting species distribution: offering more than simple habitat models. Ecology Letters 8:993-1009. http://dx.doi.org/10.1111/j.1461-0248.2005.00792.x

Guisan, A., R. Tingley, J. B. Baumgartner, I. Naujokaitis-Lewis, P. R. Sutcliffe, A. I. Tulloch, T. J. Regan, L. Brotons, E. McDonald-Madden, C. Mantyka-Pringle, T. G. Martin, J. R. Rhodes, R. Maggini, S. A. Setterfield, J. Elith, M. W. Schwartz, B. A. Wintle, O. Broennimann, M. Austin, S. Ferrier, M. R. Kearney, H. P. Possingham, and Y. M. Buckley. 2013. Predicting species distributions for conservation decisions. Ecology Letters 16:1424-1435. http://dx.doi.org/10.1111/ele.12189

Hill, D. L., H. Arañibar-Rojas, and R. MacLeod. 2008. Wattled Curassows in Bolivia: abundance, habitat use, and conservation status. Journal of Field Ornithology 79:345-351. http://dx.doi. org/10.1111/j.1557-9263.2008.00193.X

Kattan, G. H., M. C. Muñoz, and D. W. Kikuchi. 2015. Population densities of curassows, guans, and chachalacas (Cracidae): effects of body size, habitat, season, and hunting. Condor 118:24-32. http://dx.doi.org/10.1650/CONDOR-15-51.1

Lucas, C. M., P. Sheikh, P. R. Gagnon, and D. G. McGrath. 2016. How livestock and flooding mediate the ecological integrity of working forests in Amazon River floodplains. Ecological Applications 26:190-202. http://dx.doi.org/10.1890/14-2182

Macchi, L., and H. R. Grau. 2012. Piospheres in the dry Chaco: contrasting effects of livestock puestos on forest vegetation and bird communities. Journal of Arid Environments 87:176-187. http://dx.doi.org/10.1016/j.jaridenv.2012.06.003

MacKenzie, D. I., and L. L. Bailey. 2004. Assessing the fit of siteoccupancy models. Journal of Agricultural, Biological, and Environmental Statistics 9:300-318. http://dx.doi. org/10.1198/108571104X3361

MacKenzie, D. I., J. D. Nichols, G. B. Lachman, S. Droege, J. Andrew Royle, and C. A. Langtimm. 2002. Estimating site occupancy rates when detection probabilities are less than one. Ecology 83:2248-2255. http://dx.doi.org/10.1890/0012-9658(2002) 083[2248:ESORWD]2.0.CO;2
MacKenzie, D. I., J. D. Nichols, J. A. Royle, K. H. Pollock, L. L. Bailey, and J. E. Hines. 2006. Occupancy estimation and modeling. inferring patterns and dynamics of species occurrence. Elsevier/ Academic Press, Burlington, Massachusetts, USA. [online] URL: https://pubs.er.usgs.gov/publication/5200296

MacKenzie, D. I., and J. A. Royle. 2005. Designing occupancy studies: general advice and allocating survey effort. Journal of Applied Ecology 42:1105-1114. http://dx.doi.org/10.1111/ j.1365-2664.2005.01098.x

MacKenzie, D. I., J. A. Royle, J. A. Brown, and J. D. Nichols. 2004. Occupancy estimation and modeling for rare and elusive populations. Pages 149-172 in W. L. Thompson, editor. Sampling rare or elusive species: concepts, designs, and techniques for estimating population parameters. Island Press, Washington D.C., USA.

Manly, B. F. J., L. L. McDonald, D. L. Thomas, T. L. McDonald, and W. P. Erickson. 2002. Resource selection by animals: statistical design and analysis for field studies. Second edition. Kluwer Academic Publishers, Norwell, Massachusetts, USA. http://dx. doi.org/10.1007/978-94-011-1558-2

Marinho, P. H., D. Bezerra, M. Antongiovanni, C. R. Fonseca, and E. M. Venticinque. 2018. Estimating occupancy of the Vulnerable northern tiger cat Leopardus tigrinus in Caatinga drylands. Mammal Research 63:33-42. http://dx.doi.org/10.1007/ s13364-017-0330-4

McCullagh, P. 1984. Generalized linear models. European Journal of Operational Research 16:285-292. http://dx.doi.org/10.1016/0377-2217 (84)90282-0

Melo-Vasquez, I., J. M. Ochoa-Quintero, H. F. Lopez-Arevalo, and P. Velasquez-Sandino. 2008. Potential habitat loss and subsistence hunting of Blue Billed Curassow (Crax alberti), a Colombian critically endangered endemic bird. Caldasia 30:161-177.

Ministerio de Ambiente y Desarrollo Sustentable y Aves Argentina (MAyDS and AA). 2017. Categorización de las Aves de la Argentina 2015. Informe del Ministerio de Ambiente y Desarrollo Sustentable de la Nación y de Aves Argentinas. Buenos Aires, Argentina.

Muñoz, M., and G. Kattan. 2007. Diets of cracids: How much do we know? Ornitología Neotropical 18:21-36.

Muñoz, M. C., G. A. Londoño, M. M. Rios, and G. H. Kattan. 2007. Diet of the Cauca Guan: exploitation of a novel food source in times of scarcity. Condor 109:841-851. http://dx.doi. org/10.1650/0010-5422(2007)109[841:DOTCGE]2.0.CO;2

O'Connell, A. F., and L. L. Bailey. 2011. Inference for occupancy and occupancy dynamics. Pages 191-204 in A. F. O'Connell, J. D. Nichols, and K. U. Karanth. Camera traps in animal ecology. Springer, Tokyo, Japan. http://dx.doi.org/10.1007/978-4-431-99495-4_11

Oliveira, P. R., Jr., M. C. Costa, L. F. Silveira, and M. R. Francisco. 2016. Genetic guidelines for captive breeding and reintroductions of the endangered Black-fronted Piping Guan, Aburria jacutinga (galliformes, cracidae), an Atlantic Forest endemic. Zoo Biology 35:313-318. http://dx.doi.org/10.1002/ zoo. 21296 
Pardo, L. E., L. Lafleur, R. M. Spinola, J. Saenz, and M. Cove. 2017. Camera traps provide valuable data to assess the occurrence of the Great Curassow Crax rubra in northeastern Costa Rica. Neotropical Biodiversity 3:182-188. http://dx.doi. org/10.1080/23766808.2017.1346548

Pearson, R. G., and T. P. Dawson. 2003. Predicting the impacts of climate change on the distribution of species: Are bioclimate envelope models useful? Global Ecology and Biogeography 12:361-371. http://dx.doi.org/10.1046/j.1466-822X.2003.00042. $\mathrm{x}$

Peres, C. A., and H. S. Nascimento. 2006. Impact of game hunting by the Kayapó of south-eastern Amazonia: implications for wildlife conservation in tropical forest indigenous reserves. Biodiversity \& Conservation 15:2627-2653. http://dx.doi. org/10.1007/s10531-005-5406-9

Placci. G. 1995. Estructura y comportamiento fenológico en relación a un gradiente hídrico en bosques del este de Formosa. Dissertation. Facultad de Ciencias Naturales y Museo, Universidad Nacional de La Plata, La Plata, , Argentina.

Placci, G., and S. Holz. 2004. Patrón de paisaje de bosques del Chaco Oriental. In J. F. Goya, J. L. Frangi and M. F. Arturi, editors. Ecología y manejo de los bosques de Argentina. Editorial de la Universidad Nacional de La Plata, La Plata, Argentina.

Putz, F. E., D. P. Dykstra, and R. Heinrich. 2000. Why poor logging practices persist in the tropics. Conservation Biology 14:951-956. http://dx.doi.org/10.1046/j.1523-1739.2000.99137.x

R Core Team. 2018. R: a language and environment for statistical computing. R Foundation for Statistical Computing, Vienna, Austria. [online] URL: https://www.R-project.org/

Rahbek, C., and G. R. Graves. 2001. Multiscale assessment of patterns of avian species richness. Proceedings of the National Academy of Sciences of the United States of America 98:4534-4539. http://dx.doi.org/10.1073/pnas.071034898

São Bernardo, C. S. 2012. Reintroduction as a conservation tool for threatened Galliformes: the Red-billed Curassow Crax blumenbachii case study from Rio de Janeiro state, Brazil. Journal of Ornithology 153:135-140. http://dx.doi.org/10.1007/s10336-011-0805$\mathrm{z}$

Stern, M., M. Quesada, and K. E. Stoner. 2002. Changes in composition and structure of a tropical dry forest following intermittent cattle grazing. Revista de Biología Tropical 50:1021-1034.

Thornton, D. H., L. C. Branch, and M. E. Sunquist. 2012. Response of large galliforms and tinamous (Cracidae, Phasianidae, Tinamidae) to habitat loss and fragmentation in northern Guatemala. Oryx 46:567-576. http://dx.doi.org/10.1017/ S0030605311001451
Tortato, F. R., T. J. Izzo, R. Hoogesteijn, and C. A. Peres. 2017. The numbers of the beast: valuation of jaguar (Panthera onca) tourism and cattle depredation in the Brazilian Pantanal. Global Ecology and Conservation 11:106-114. http://dx.doi.org/10.1016/ j.gecco.2017.05.003

Townsend, W. R., D. I. Rumiz, and L. Solar. 2002. El riesgo de la cacería durante las operaciones forestales: Impacto sobre la fauna silvestre en una concesión forestal en Santa Cruz. Revista Boliviana de Ecología y Conservación Ambiental 11:47-53.

Tracewski, Ł., S. H. Butchart, M. Di Marco, G. F. Ficetola, C. Rondinini, A. Symes, H. Wheatley, A. E. Beresford, and G. M. Buchanan. 2016. Toward quantification of the impact of 21stcentury deforestation on the extinction risk of terrestrial vertebrates. Conservation Biology 30:1070-1079. http://dx.doi. org/10.1111/cobi.12715

Wallace, R. B., R. L. E. Painter, D. I. Rumiz, L. Sainz, and A. B. Taber. 2001. Comparative ecology of cracids in northern Dpto. SantaCruz, Bolivia. Pages 68-86 in D. M. Brooks and F. GonzálezGarcia, editors. Cracid ecology and conservation in the new millenium. Miscellaneous Publications of the Houston Museum of Natural Science 2. Houston, Texas, USA.

White, E. E. 2001. Estancia Guaycolec como un área importante para la conservación de Crax $f$. fasciolata y Penelope o. obscura en el Chaco húmedo de Formosa. Argentina. Bulletin of the IUCN/BirdLife/WPA Cracid Specialist Group 13:14-18.

Willis, K. J., and R. J. Whittaker. 2002. Species diversity-scale matters. Science 295:1245-1248. http://dx.doi.org/10.1126/ science. 1067335

Wisz, M. S., J. Pottier, W. D. Kissling, et al. 2013. The role of biotic interactions in shaping distributions and realised assemblages of species: implications for species distribution modelling. Biological Reviews 88:15-30. http://dx.doi.org/10.1111/ j.1469-185X.2012.00235.x

Zamboni, T., S. Di Martino, and I. Jiménez-Pérez. 2017. A review of a multispecies reintroduction to restore a large ecosystem: the Iberá Rewilding Program (Argentina). Perspectives in Ecology and Conservation 15:248-256. http://dx.doi.org/10.1016/j.pecon.2017.10.001
Editor-in-Chief: Ryan Norris Subject Editor: Katie E.Sieving
Sponsored by the Society of Canadian Ornithologists and Bird Studies Canada Parrainée par la Société des ornithologistes du Canada et Études d'oiseaux Canada

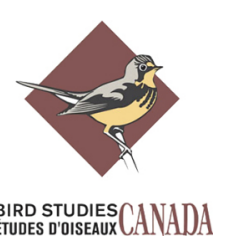

